\title{
LITERARY WASTELANDS: A STUDY OF J. R. R. TOLKIEN, VIRGINIA WOOLF, AND T. S. ELIOT'S RESPONSES TO THE PROBLEMS ARISING FROM WWI
}

\author{
Fabian Quevedo da Rocha
}

Submetido em 16 de abril de 2019.

Aceito para publicação em 26 de agosto de 2019.

Cadernos do IL, Porto Alegre, n. ${ }^{\circ}$ 58, outubro. p. 109-120.

\section{POLÍTICA DE DIREITO AUTORAL}

Autores que publicam nesta revista concordam com os seguintes termos:

(a) Os autores mantêm os direitos autorais e concedem à revista o direito de primeira publicação, com o trabalho simultaneamente licenciado sob a Creative Commons Attribution License, permitindo o compartilhamento do trabalho com reconhecimento da autoria do trabalho e publicação inicial nesta revista.

(b) Os autores têm autorização para assumir contratos adicionais separadamente, para distribuição não exclusiva da versão do trabalho publicada nesta revista (ex.: publicar em repositório institucional ou como capítulo de livro), com reconhecimento de autoria e publicação inicial nesta revista.

(c) Os autores têm permissão e são estimulados a publicar e distribuir seu trabalho online (ex.: em repositórios institucionais ou na sua página pessoal) a qualquer ponto antes ou durante o processo editorial, já que isso pode gerar alterações produtivas, bem como aumentar o impacto e a citação do trabalho publicado.

(d) Os autores estão conscientes de que a revista não se responsabiliza pela solicitação ou pelo pagamento de direitos autorais referentes às imagens incorporadas ao artigo. A obtenção de autorização para a publicação de imagens, de autoria do próprio autor do artigo ou de terceiros, é de responsabilidade do autor. Por esta razão, para todos os artigos que contenham imagens, o autor deve ter uma autorização do uso da imagem, sem qualquer ônus financeiro para os Cadernos do IL.

\section{POLÍTICA DE ACESSO LIVRE}

Esta revista oferece acesso livre imediato ao seu conteúdo, seguindo o princípio de que disponibilizar gratuitamente o conhecimento científico ao público proporciona sua democratização.

http://seer.ufrgs.br/cadernosdoil/index

Segunda-feira, 07 de outubro de 2019. 


\title{
LITERARY WASTELANDS: A STUDY OF J. R. R. TOLKIEN, VIRGINIA WOOLF, AND T. S. ELIOT'S RESPONSES TO THE PROBLEMS ARISING FROM WWI
}

\author{
TERRAS DESOLADAS LITERÁRIAS: UM ESTUDO DAS \\ RESPOSTAS DE J. R. R. TOLKIEN, VIRGINIA WOOLF, E \\ T. S. ELIOT AOS PROBLEMAS DECORRENTES DA \\ PRIMEIRA GUERRA MUNDIAL
}

Fabian Quevedo da Rocha*

\begin{abstract}
This article discusses how the image of the world as a wasteland is used by J. R. R. Tolkien in The Lord of the Rings and The Hobbit, Virginia Woolf in her To the Lighthouse, and T. S. Eliot in The Wasteland, to comment on the damage caused by WWI. In it, it is argued that although such image is present in the works of the three writers, different ideas are being underscored: while the works of Eliot and Woolf are marked by feelings of fragmentation and alienation, Tolkien's narrative argues for the importance of fellowship during times of great turmoil. By relying on Theresa Nicolay's studies, this work debates how these authors use different techniques to address similar problems.
\end{abstract}

KEYWORDS: J. R. R. Tolkien; Literary Wastelands; T. S. Eliot; Virginia Woolf.

RESUMO: Este artigo discute como a imagem do mundo como terra desolada é usada por J. R. $R$. Tolkien em O Senhor dos Anéis e O Hobbit, Virginia Woolf em Ao Farol e T. S. Eliot em A Terra Desolada para abordar os danos causados pela Primeira Guerra Mundial. Nele, discute-se que embora tal imagem esteja presente nas obras dos três escritores, ideias diferentes estão sendo enfatizadas: enquanto as obras de Eliot e Woolf são marcadas por sentimentos de alienação e fragmentação, a narrativa de Tolkien aborda a importância da união durante tempos de grande caos. Com base nos estudos de Theresa Nicolay, este trabalho discute como tais autores utilizam técnicas diferentes, para abordar problemas semelhantes.

PALAVRAS-CHAVE: J. R. R. Tolkien; Terras desoladas literárias; T. S. Eliot; Virginia Woolf.

\section{Introduction}

A recurrent image in the literature of the first half of the 20th century is that of the world as a wasteland. It may be seen, in greater or lesser degrees, in works such as Virginia Woolf's To the Lighthouse, Tolkien's The Lord of the Rings ${ }^{1}$ and The Hobbit, and, of course, in Eliot's eponym poem The Wasteland ${ }^{2}$. This frequently used image is,

\footnotetext{
* Doutorando da Universidade Federal do Rio Grande do Sul, Mestre pela Universidade Federal do Rio Grande do Sul, fabianway07@gmail.com.

${ }^{1}$ Tolkien's The Lord of the Rings was published between 1954 and 1955. However, the author composed the book between 1936 and 1949. In this sense, the work emerged from the same atmosphere as did the works of Fitzgerald, Woolf, and Eliot mentioned above.

${ }^{2}$ My option for these specific authors and works was guided by Theresa Freda Nicolay's (2014) study about the literature produced in the first half of the twentieth century.
} 
as Theresa Freda Nicolay (2014) suggests, an objective correlative ${ }^{3}$ to express these authors' sense of desolation after World War I. In this sense, the wastelands these writers present are not only external, but also internal: it is not uncommon to find in their narratives characters that lose hope and despair before the dreary reality that surrounds them. It is important to point out, however, that even though these authors were reacting to the same crisis and depicting the world in a similar way, that does not mean that their answers were the same. One of the main differences between the works of T. S. Eliot and Virginia Woolf, and the ones by Tolkien lies in the "[...] possibility of hope that their imaginative constructions offer for posterity" (NICOLAY, 2014, p. 7). While Woolf's To the Lighthouse and Eliot's The Wasteland underscore the damage caused by the crisis of their time, Tolkien's The Lord of the Rings and The Hobbit tend to focus on the power of fellowship and community building as a means to overcome difficult times. This difference, Nicolay argues, has to do, to a considerable extent, with the way these writers engaged with the past.

Literary writing means, inevitably, engaging with the past. One is constantly being influenced by their own life experiences: books they have read, places they have visited, the way they have been brought up, contexts in which they have lived, and so on. In this sense, even though writers may attempt to break free from "old forms and conventions" and create something entirely new, their works will often carry with them (willingly or unwillingly) some trace of influence from the past, as if in constant dialogue with the works of the writers that preceded them. It is true that some writers do it more consciously and deliberately (which is Tolkien's case) than others, but they all do it, nonetheless. Therefore, considering what literary traditions most profoundly influenced Tolkien, Eliot, and Woolf is of significant importance for a broader understanding of how their responses to the problems arising from WWI differ.

Tolkien was a philologist, in this sense, the author obviously had a keen interest in languages, which led him to be well versed in a considerable number of them, namely Old English, Middle English, Old Norse, Latin, Greek, and Gothic. While studying them, Tolkien often came across ancient (literary) texts which called his attention. Among them were the Old Norse Elder Edda and the Old English poem Beowulf, which had a profound influence in his works. Besides being a philologist, Tolkien was also a Roman Catholic from his youth: he was raised in the catholic faith first by Mabel Tolkien, his mother, and then, after her death when he was only 13, by Father Francis Xavier Morgan, a friend of the family and Mabel's appointed tutor. Tolkien saw in the Biblical narratives, as well as in the ancient texts he studied, timeless values that contained, as Nicolay (2014) suggests, the wisdom of the past that can guide our present actions. Among these values are faith, compassion, forgiveness towards the ones around us, and the courage to act for the good of the community rather than for the benefit of the self. The ideals of selflessness were, for Tolkien, the foundational stones upon which human community rests.

Even though the works by Eliot and Woolf expressed similar concerns for the world as Tolkien's, these writers "[...] followed the intellectual trajectory of the nineteenth century, creating characters that are deeply self-absorbed and addressing themes of profound loss, faithlessness, disaffection, loneliness, and alienation" (NICOLAY, 2014, p. 17). Such themes are present, for example, not only in the poetry

\footnotetext{
${ }^{3}$ A term used by T. S. Eliot in his essay Hamlet and his Problems (1920) to describe a mode of using things that are external to the self (e.g.: a set of objects, an event, or a chain of events) as a means to express internal states or feelings.
} 
by Eliot and in the novels by Woolf, but also in the short stories of James Joyce, and in some works of F. Scott Fitzgerald. This is not to say, however, that Tolkien did not address these topics, nor that some of his characters were not self-absorbed. That would be far from the truth, but in the majority, his characters are selfless, and his narrative embodies the values of love, kindness and humility. The difference is, to a considerable extent, not on what these writers wrote, but rather on how they did it: though Tolkien, Woolf, and Eliot are all part of the literary modernism, the mode they endorsed to write the works I discuss in this article are different; while Tolkien used fantasy, Woolf and Eliot chose realism. With that in mind, in the next section I will contrast and comment on excerpts in which these writers depict the external and internal wastelands of their time.

\section{External and internal wastelands}

T. S. Eliot, one of the most important and influential poets of the twentieth century, wrote prolifically about the material and spiritual damage of WWI. His poetry often puts forth images of internal and external desolation, which is the case of his The Love Song of J. Alfred Prufrock. Prufrock, as Nicolay argues, "[...] dwells in a dirty industrialized London, the origins of which reach back to the time of Blake." (NICOLAY, 2014, p. 34). Such poem is filled with images of oppressive yellow fogs and smoke that rub against windowpanes and slide along the streets as well as of soot that falls from chimneys. People in the poem are described as "eyes" and "arms that are braceleted and white and bare" and Prufrock knows them all already (ELIOT, 1998, p. 8). Streets in the poem are lonely, while restaurants and hotels are dirty which renders human connection debased rather than life-affirming. Throughout the poem, it is possible to see Prufrock trying to connect with others, but at the same time getting paralyzed by fear of such connection.

The Waste Land, on the other hand, since its publishing in 1922, has become one of the most studied modernist texts in English literature courses. It is, among many other things, a poem of breakdowns: there is the breakdown of the poetical form and language, there is psychological breakdown, and there is also the breakdown of the world. The aftermath of the World War I left most people that had lived through it devastated. In his four hundred and thirty-four-line-long masterpiece, Eliot managed to mirror the internal and external desolation of his time. The poem opens with lines from Petronius's Satyricon in which a group of boys ask the Cumaean Sybil what she wants; the Sybil, who requested longevity from Apollo, but had forgotten to ask also for eternal youth, answers that she wants to die. As one ventures through Eliot's poem, they are shown a barren landscape that offers no promise of hope, as it may be argued from the first stanzas of The Burial of the Dead: "April is the cruellest month, breeding/ Lilacs out of the dead land, mixing/ Memory and desire, stirring/ Dull roots with spring rain./ Winter kept us warm, covering/ Earth in forgetful snow, feeding/ A little life with dried tubers." (ELIOT, 1998, p. 32-33). Instead of bringing joy and hope instilled by the beginning of Spring, in Eliot's poem April brings torment since it stirs feelings and memories of the damage and suffering caused by the war. It seems to be a direct reference to the Spring Offensive of March 1918, a series of German attacks along the Western front that caused the death of thousands of people from each side of the 
conflict. Winter, on the other hand, brings comfort since, as Nicolay (2014) suggests, it brings forgetfulness with its snow that covers the poem's speaker consciousness.

The people the speaker sees crossing London Bridge seem to the speaker in the poem to have been undone by death. In addition to that, towards the end of the poem, in the first stanza of What the Thunder Said, Eliot recalls the sufferings of Jesus in the Garden of Gethsemane and his subsequent death: "He who was living is now dead/ We who were living are now dying" (ELIOT, 1998, p. 47).

This sense of despair and loss conveyed in Eliot's poetry is also present in Woolf's novel To the Lighthouse. It seems as if these writers were largely concerned with capturing in words the pain and horror of the modern age, the drama of living in the first half of the 20th century; Virginia Woolf's To the Lighthouse is a precise demonstration of that. In such work, written in the years between WWI and WWII, Woolf masterfully depicts the complexity of modern consciousness through the stream of consciousness ${ }^{4}$ technique. As opposed to the novels of Victorian writers, such as George Elliot and Charles Dickens, that often focused on external details, Woolf tries to convey how the characters in her work perceive their surroundings and how they make them feel inside. This is not to say, however, that her novel does not deal with mundane affairs and themes (because it often does), nor that she was not influenced by her predecessors (Elliot's influence in her works is hard to be missed), but rather that Woolf was trying to endorse a new kind of realism. Since the writer lived through chaotic and confusing times, her works frequently conveyed the mental confusion and chaos of people living in that period. It is as if Woolf thought that since the period she was living was confusing, the works of art must be confusing too. The internal and external desolation of her time, as I will attempt to demonstrate, is strongly present in To the Lighthouse.

To the Lighthouse opens with a day in the life of the Ramsay's family. All through the lengthy first chapter of the novel, The Window, the narrator offers a careful insight of the character's feelings and concerns. It is curious to notice that even though the characters in this chapter are all gathered in the Ramsay's summer house in Scotland for a fancy dinner, in which one would expect they would strengthen their bonds while connecting with one another and celebrating their friendship, the characters, in fact, are painfully reminded of the inadequacy of human relationships, of their own insecurities and the difficulty of trusting one another. This chapter, as well as the rest of the book, is filled with scenes that represent the potential for meaning and harmony in human existence; however, these are merely glimpses of what could have been. What predominates in the novel is the sense of despair and hopelessness as expressed by Mrs. Ramsay: "With her mind she had always seized the fact that there is no reason, order, justice: but suffering, death, the poor. There was no treachery too base for the world to commit; she knew that. No happiness lasted; she knew that." (WOOLF, 1992, p. 124).

It is interesting to notice that even though the first part of the novel is set in a pre-WWI period (1910), there is a feeling of desolation that looms over the narrative all through the chapter; such feeling grows as the work progresses. Chapter two, Time Passes, the shortest in the novel, takes place ten years after the dinner party in the Ramsay's Summer house. Much has changed since then: Mrs. Ramsay has died as well as two of her children. Prue died due to complications of childbirth while Andrew was

\footnotetext{
${ }^{4}$ A writing technique made famous by James Joyce and largely used by modernist writers. It represents, as Drabble suggests, "the 'flow' of impressions, memories, and sense-impressions through the mind by abandoning accepted forms of syntax, punctuation, and logical connection." (DRABBLE, 2000, p. 975).
} 
killed by a shell explosion during the war. The house they used to spend the Summer had also changed; the only life in it, as we are informed, is a lesser wind; apart from that

Nothing stirred in the drawing-room or in the dining-room or on the staircase. Only through the rusty hinges and swollen sea-moistened woodwork certain airs, detached from the body of the wind (the house was ramshackle after all) crept round corners and ventured indoors. (WOOLF, 1992, p. 124).

The way the house is depicted in chapter II, as Nicolay argues, bears profound meaning:

\begin{abstract}
In the world of the novel, the Ramsay's house has come to stand for the literal and figurative losses as well as feelings of emptiness brought about by World War I. On a literal level, the Ramsays have precipitously lost family members (...). This personal loss corresponds to the loss of loved ones in the real world of Woolf and her readers. On a figurative level, the disembodied "airs" that wander about the house correspond to the feelings of aimlessness and rootlessness that were part of the modernist sensibility. In other words, the desolate house can be viewed as an objective correlative for the modern wasteland and its inhabitants. (NICOLAY, 2014, p. 104).
\end{abstract}

Like Eliot's The Waste Land, the tone of Woolf's novel is one of resignation and despair. All through the novel there are, of course, glimpses of hope such as in chapter II when Prue Ramsay is given in marriage in the middle of Spring. People ask, the narrator declares, what could have been more fitting than being given in marriage during the Spring, the season of life, of hope, of promise and persisting dreams. What could go wrong in such a season in which nature itself seems to declare that there is order in the world, that happiness prevails and good triumphs in the end? However, soon after being offered, the feeling of hope shatters and is taken away from the readers and is replaced by Prue's premature death. After brief moments of hope, "we are faced again with inevitable loss and a sense of despair because any vision of transcendence is so fleeting that it seems more like an illusion than a reality." (NICOLAY, 2014, p. 105106). For all our penitence and toil, as Woolf suggests in her novel, we deserve only glimpses and fragments of divine goodness from which we can only try, but never succeed in composing a perfect whole or reading clear words of truth. Amidst the postwar chaos in Woolf's novel, not only is the world fragmented, but also the human beings are shattered. Connection is almost impossible and all one can do is, as Lilly Briscoe does in the beginning of chapter III, The Lighthouse, wonder what could it mean to carry on with a sense of being adrift and without being able to express one's feelings before the internal barrenness of the self and the external wasteland that the world had been turned into.

According to Nicolay (2014), such tone is recurrent in many of the works produced in England during the first half of the twentieth century and can be seen as an answer not only to the problems arising from WWI, but also to changes that emerged in the previous century, such as:

[...] The rise of industrialism and capitalism; new theories in science, the social sciences, and the arts; changing attitudes toward religion and politics; and an apparent diminution of the quality of human experience in terms of both the individual and the community. (NICOLAY, 2014, p. 2). 
Anthony Burgess (1974) adds to what Nicolay proposes by stating that the literature produced at the turn of the nineteenth century is characterized, at times, by an attempt to find substitutes for a religion that is apparently dead, and at others by a desperate desire to find something to believe. In other words, the writers of the first half of the twentieth century were trying to figure out how to carry on after the several consequences arising from an environment of great social change, and, in order to do that, they were looking for answers that could help them make sense of this new order of things.

However, if, on one hand, the works by Eliot and Woolf tend to emphasize alienation and despair and depict characters that have turned almost completely inward, the narratives by Tolkien, on the other hand, call attention to the importance of fellowship and hope during periods of great toil and pain. The internal and external wastelands are present, in greater or lesser degrees, in all of his works about Middleearth; however, the characters' actions in the face of adversity and of the damage done to the world diverge most profoundly from what is proposed in the works by Eliot and Woolf. The state of paralysis, so common in the narratives of the first half of the 20th century, rarely makes an appearance in the Tolkienian works. Tolkien believed that change required action, mainly collective action, that is why his narratives tend to underscore the importance and power of "the role of the individual in promoting and sustaining both the human community and the natural world in the face of those forces that would make a wasteland of it." (NICOLAY, 2014, p. 6). This major difference in the way hope and perspective are proposed in the works by Tolkien and in the ones by Eliot and Woolf is associated, to a great extent, to the mode these authors chose: Eliot's poetry and Woolf's novels are often permeated with realism; consequently, the characters in these writers' works are frequently too immersed in reality to have the necessary strength to go beyond their weaknesses, which makes feelings of despair and fragmentation recurrent in these narratives. In addition to that, the fictional world which the characters in Eliot's and Woolf's works inhabit is normally presented as an objective correlative of these character's feelings; that is why such worlds are often depicted as dreary and hostile wastelands that offer little perspective of hope. Differently from Woolf and Eliot, Tolkien recurred to fantasy to build his narratives. The author believed, as it is expressed in his essay "On Fairy Stories", that such literary mode started with an advantage over more realistic fiction; such advantage the author called "arresting strangeness", which means basically that fantasy has the narrative potential of immersing readers in a fantastic universe. In such fantastic setting, things which are not feasible or likely to happen in the real world are made possible by the use of fantasy. In this sense, even though the Tolkienian narratives also present characters facing the adversities deriving from wars and the difficulties of living in a land devastated by such conflicts, what is often underscored is the power and importance of fellowship as a means to overcome the crisis. With examples from The Hobbit and then with excerpts of The Lord of the Rings, I intend to demonstrate how this is so.

The Hobbit, published in 1937, tells the story of how Bilbo Baggins, a peaceful hobbit, "had an adventure, and found himself doing and saying things altogether unexpected" for one of his kind (TOLKIEN, 2014, p. 4). It is the account of how Bilbo managed to unite the peoples of Middle-earth (men, elves and dwarfs) in favor of a greater good. In it, he is recruited by a group of 13 dwarfs to go on a lengthy journey from the Shire, his homeland situated in the Western region of Middle-earth, to the 
Lonely Mountains, located in the uttermost East, in order to reclaim the Dwarfs' home and treasure in the mountains, that had been taken from them by the ruthless and fearsome dragon Smaug. Even prior to the beginning of the quest, all the party knows that there is little hope of success and that the consequences of their attempt may be catastrophic; yet, they know that this little chance of success depends on their own efforts. Consequently, they start their pilgrimage hoping for the best and trusting on the success of their mission. However, when after much toil they approach the final stage of their quest and are faced with the wasteland that their homeland had become, hope, as the narrator tells us, starts to vanish from their hearts:

\begin{abstract}
It was a weary journey, and a quiet and stealthy one. There was no laughter or song or sound of harps, and the pride and hopes which had stirred in their hearts at the singing of old songs by the lake died away to a plodding gloom. They knew that they were drawing near to the end of their journey, and that it might be a very horrible end. The land about them grew bleak and barren, though once, as Thorin told them, it had been green and fair. There was little grass, and before long there was neither bush nor tree, and only broken and blackened stumps to speak of ones long vanished. They were come to the Desolation of the Dragon, and they were come at the waning of the year. (TOLKIEN, 2014, p. 235).
\end{abstract}

It is important to notice, however, that even when hope starts to die and all the dwarfs begin to think the quest has failed, Bilbo refuses to give up; from his persistence, a solution arises and the dragon, after causing much havoc and killing many of the citizens that lived in Lake-town, a small town nearby the Lonely Mountains, is killed. With Smaug slain, the dwarfs reclaimed their dwelling in the mountains and also their treasure. However, as news of the dragon's demise spread, peoples from different regions of Middle-earth, thinking the dwarfs had been killed by the dragon, set forth to the Lonely Mountain to take a share of the treasure that lay there. Among these peoples was Bard, who was hoping to use part of the treasure to rebuild his city which had been utterly destroyed by Smaug. With Bard were also the elves from Mirkwood, who had learned about the disaster that had struck their friends from Lake-town and were willing to help as well as claim a share of the treasure. Most of the dwarfs, however, were unwilling to share any portion of their gold, not even with the people of Lake-town that had helped them reclaim their home and had suffered a great loss. The argument concerning the division of the treasure reaches so great a proportion that the dwarfs declare war to the people from Lake-town and the elves. However, when war between them is about to break, Bilbo and Gandalf ${ }^{5}$ manage to call their attention to an imminent danger that threatens to destroy them all: a great host of goblins is marching towards them, seeking revenge from previews grievances and lusting for gold. Putting their differences aside, the elves, the men from Lake-town and the dwarfs unite to face the hosts of goblins, enemies of them all. By their union they manage, after great loss, to defeat the goblins' armies and "now the northern world would be merrier for many a long day. The dragon was dead, and the goblins overthrown, and their hearts looked forward after winter to a spring of joy." (TOLKIEN, 2014, p.338). After the victory, the quarrel over the treasure is settled, the dwarfs finally agree to share part of the hoard,

\footnotetext{
${ }^{5}$ A spiritual being that is sent to Middle-earth during the third age of that world to aid the free peoples of that world in the struggles against the evil powers of Sauron. While on Middle-earth, he took the shape of an old wise man and was perceived as a wizard.
} 
and Bilbo, then, returns to his home in the West. Some years after his adventures, however, Gandalf and one of the dwarfs pay him a visit; the hobbit, then, decides to ask them how things are going in the East and, to his delight, he is informed that

\begin{abstract}
[i]t seemed they were going very well. Bard had rebuilt the town in Dale and men had gathered to him from the Lake and from South and West, and all the valley had become tilled again and rich, and the desolation was now filled with birds and blossoms in spring and fruit and feasting in autumn. And Lake-town was refounded and was more prosperous than ever, and much wealth went up and down the Running River; and there was friendship in those parts between elves and dwarves and men. (TOLKIEN, 2014, p. 349$350)$
\end{abstract}

It is interesting to notice how the possibility of hope and prosperity diverge from Tolkien's narrative to the ones by Eliot and Woolf: while in the first the characters are seen coming together to overcome the hardships they are faced with as a way to restore order amidst chaos, in the narratives by the latter the failure of communication and community is often underscored as the characters turn inward and become paralyzed by feelings of despair. If the Spring in Eliot's Waste Land and in Woolf's To the Lighthouse seems to fail to bring joy and hope, in Tolkien's work it is a sign of forthcoming plenitude and peace. Similar contrasts can be seen even more prominently in The Lord of the Rings.

The plot of The Lord of the Rings revolves, to a great extent, around the struggles and toils of the free peoples of Middle-earth (men, hobbits, elves, and dwarfs) against the powers of Sauron ${ }^{6}$ and its subordinates who threaten to turn all the land in a wasteland. Mainly, it tells of how a group of nine companions, called the Fellowship of the Ring, united under a common goal: overthrown Sauron and prevent him of causing further destruction. During their many journeyings across Middle-earth, the characters in the Fellowship of the Ring must struggle against the growing desolation caused by Sauron and his servants, and also against their own fears. The success of their mission depends, on one hand, on their understanding of their duty towards their people and also on their capacity to endure the hardships they are faced with; on the other hand, on the recognition that their hopes lie both on individual effort and on the power of fellowship, for "[i]ndeed in nothing is the power of the Dark Lord more clearly shown than in the estrangement that divides all those who still oppose him" (TOLKIEN, 2007, p. 453).

One of the themes that is often underscored throughout The Lord of the Rings is that of the importance of human connection and fellowship, mainly during times of great distress and turmoil, so much so that the group that sets from Rivendell ${ }^{7}$ after the Council of Elrond is named "The Fellowship of the Ring". It is interesting to notice, however, what exactly this fellowship represents: in a broader sense, it is a group of people that unite as a means to accomplish a difficult and dangerous task; but in another sense, that is often overlooked, it is also a group formed by totally different individuals belonging from different races that have different cultures, languages, beliefs, and values, but who have decided to set their differences aside and let go of their personal desires to follow an appointed path, for a common greater good. Starting with the four

\footnotetext{
${ }^{6}$ A spiritual being in The Lord of the Rings. Sauron is the chief enemy of the Free Peoples of Middleearth and the major threat in Tolkien's fictional universe.

${ }^{7}$ An elven refuge founded by Elrond, lord of that city, during the Second-Age of Middle-earth. Located East of the Shire, the city became the main center of elfish culture in Middle-earth.
} 
hobbits: they are not used to the dangerous life out of the Shire; more than that, they do not seem to know what to do, nor how to behave in the world beyond the borders of their homeland, so much so that they often feel helpless and regret their decision of joining the Fellowship:

\footnotetext{
'I wish I had taken Elrond's advice,' muttered Pippin to Sam. 'I am no good after all. There is not enough of the breed of Bandobras the Bullroarer in me: these howls freeze my blood. I don't ever remember feeling so wretched.' 'My heart's right down in my toes, Mr. Pippin,' said Sam. 'But we aren't etten yet, and there are some stout folk here with us. (TOLKIEN, 2007, p. $388)$
}

As it can be argued from the excerpt above, the hobbits believe they do not possess the necessary courage that is needed to accomplish the task they decided to accept. Passages like the aforementioned, recur all through the narrative; however, none of the hobbits turn back or give up, both because they know they are not alone and also because they are somehow aware that they have a role to play in the affairs of Middleearth.

Probably one of the most remarkable achievements of the Fellowship of the Ring in terms of human connection is its potential of settling one of the oldest and most long-lasting enmities in the history of Middle-earth, that between dwarves and elves. The grievances between these two peoples date back to the First Age of Middle-earth and was, at first, connected to their lust of the Silmarils, gems of immense beauty crafted by Fëanor, a renowned elfish craftsman and warrior of that time. This conflict, which had been greatly appeased by the beginning of the Second Age, was rekindled once more by Sauron, who managed to disseminate discord in these peoples' hearts. By this point in history on, dwarfs and elves started to regard each other with growing mistrust and rivalry. Curiously enough, there is a representative of each of these races in the Fellowship of the Ring, Gimli and Legolas. At first, as it may be argued from the excerpt below, they were resentful towards each other and had difficulties in cooperating:

\footnotetext{
'Well, here we are at last!' said Gandalf. 'Here the Elvenway from Hollin ended. Holly was the token of the people of that land, and they planted it here to mark the end of their domain; for the West-door was made chiefly for their use in their traffic with the Lords of Moria. Those were happier days, when there was still close friendship at times between folk of different race, even between Dwarves and Elves.' 'It was not the fault of the Dwarves that the friendship waned,' said Gimli. 'I have not heard that it was the fault of the Elves,' said Legolas. 'I have heard both,' said Gandalf; 'and I will not give judgement now. But I beg you two, Legolas and Gimli, at least to be friends, and to help me. I need you both. (TOLKIEN, 2007, p. 395).
}

However, along their journey, little by little the elf and the dwarf learn to set past grievances aside and start to enjoy each other's company. In fact, towards the middle of the narrative they are already very good friends. It is interesting to notice, though, that what makes such change in their behavior possible is, to a considerable extent, their understanding of the importance of placing the well-being of the collective before personal differences and animosities; such notion may be noticed in Gandalf's discourse in the paragraph above: the wizard is aware of the historical conflicts between elves and dwarfs, but he also knows that the Fellowship's best chance of success resides in their 
uniting and working together. In the face of the growing darkness and destruction represented by Sauron, hope lies on community rather than on individuality.

Gandalf has a central function in the narrative: he is the one who guides and helps the Free-Peoples of Middle-earth in the struggles against Sauron. Despite being an extremely powerful spiritual being, Gandalf never tries to exert his powers as a means to make others follow or obey him. As Rudd (2011) points out, his chief strategies to aid his companions are his good and moral counsels as well as his encouragement; he is largely regarded by the characters in The Lord of the Rings as one of the wisest in the narrative. One of the reasons for that has to do with his notions of despair, wisdom, and necessity:

\footnotetext{
'Thus we return once more to the destroying of the Ring,' said Erestor, 'and yet we come no nearer. What strength have we for the finding of the Fire in which it was made? That is the path of despair. Of folly I would say, if the long wisdom of Elrond did not forbid me.' 'Despair, or folly?' said Gandalf. 'It is not despair, for despair is only for those who see the end beyond all doubt. We do not. It is wisdom to recognize necessity, when all other courses have been weighed, though as folly it may appear to those who cling to false hope. (TOLKIEN, 2007, p. 350-351).
}

Gandalf recognizes the importance of keeping hope alive through dark times. In fact, the character's attitudes and discourse underscore the idea that hope of success lies greatly on agency and on the recognition of its importance. Thus, throughout the narrative he propels the other characters to action for he knows that idleness would result in the triumph of the enemy. In this sense, Gandalf seems to represent a kind of outer force that urges one to action and encourages one to fight the internal and external forces that tend to paralyze and alienate the human beings in the face of chaotic times. Such force seems to be largely absent in the narratives of Eliot and Woolf.

\section{Final Considerations}

Through the course of this article, I argued that even though the narratives of Tolkien, Woolf, and Eliot shared similarities concerning the issues they address, the way their authors discuss these issues and the literary techniques they used to do so differ to a great extent. The aftermath of WWI was accompanied by increasing feelings of alienation, fragmentation, and dislocation, which generated two main literary responses: on one hand there were the works of literary modernists such as T. S. Eliot and Virginia Woolf, in which the world is depicted as a wasteland with its inhabitants lacking in faith, hope, and beliefs to hold on; on the other hand, there were the works of writers such as J. R. R. Tolkien that, similarly to the writers mentioned above, also presented a darkened world. One of the main differences between the writers in these two groups, however, has to do with the way their narratives addressed the crisis they were facing: while the first seems to choose to focus on the damage the War caused to the world and its inhabitants, the latter tends to focus on how the power of faith, selflessness, compassion, and other virtues aid people in restoring the sense of human connection, power of community-building, and belief in a hopeful future.

If, on one hand, the narratives of Woolf and Eliot often depict characters turning inward and becoming paralyzed before the crisis they are being faced, on the other hand, with the acts of the characters in The Hobbit and The Lord of the Rings, Tolkien 
manages to depict both the importance and benefits of communion as well as the dangers of self-absorption and inwardness in times of growing turmoil and distress. Neither of these authors were blind to the problems of their times; they were aware that during periods of great crisis and chaos human beings may become alienated to the point of cutting themselves off from community and, as a consequence, feel paralyzed. However, Tolkien's narratives seem to make a much stronger case for the power of union and the importance of agency during such times, so much so that it is, to a great extent, due to these aspects that, after much toil and hardships, the characters in these narratives manage to restore the balance and well-being in their fictional universe.

Therefore, it may be argued that the main difference between the works produced by Eliot, Woolf, and Tolkien has to do with the way these writers chose to convey their ideas, as well as the possibility of hope their narratives offer for posterity and the importance of fellowship in the face of difficult times. Such difference is connected, to a great extent, to the mode these authors chose to express themselves: realism, in the case of Eliot and Woolf, and fantasy, in the case of Tolkien.

\section{REFERENCES}

BURGESS, Anthony. English literature. Harlow: Pearson, 1974.

DRABBLE, Margaret. The Oxford companion to English literature. New York: Oxford, 2000 .

ELIOT, T. S. Hamlet and his problems. IN: ELIOT, T. S. The sacred wood: essays on poetry and criticism. London: Methuen, 1920. p. 87-94. Signet, 1998.

The Waste Land and other poems. (Edição de Helen Vendler). New York:

NICOLAY, Theresa Freda. Tolkien and the modernists: literary responses to the dark new days of the $20^{\text {th }}$ century. Jefferson: McFarland, 2014.

RUUD, Jay. Critical companion to J. R. R. Tolkien. New York: Facts on File, 2011.

TOLKIEN, J. R. R. The lord of the rings. 2. ed. London: Harper Collins, 2007.

The Hobbit or there and back again. London: Harper Collins, 2014.

WOOLF, Virginia. To the lighthouse. London: Penguin, 1992. 